IZA DP No. 8981

The Rise of Female Entrepreneurs: New Evidence on Gender Differences in Liquidity Constraints

Robert M. Sauer

Tanya Wilson

April 2015 


\title{
The Rise of Female Entrepreneurs: New Evidence on Gender Differences in Liquidity Constraints
}

\author{
Robert M. Sauer \\ Royal Holloway, University of London \\ and IZA \\ Tanya Wilson \\ Royal Holloway, University of London
}

Discussion Paper No. 8981

April 2015

IZA

P.O. Box 7240

53072 Bonn

Germany

Phone: +49-228-3894-0

Fax: +49-228-3894-180

E-mail: iza@iza.org

Any opinions expressed here are those of the author(s) and not those of IZA. Research published in this series may include views on policy, but the institute itself takes no institutional policy positions. The IZA research network is committed to the IZA Guiding Principles of Research Integrity.

The Institute for the Study of Labor (IZA) in Bonn is a local and virtual international research center and a place of communication between science, politics and business. IZA is an independent nonprofit organization supported by Deutsche Post Foundation. The center is associated with the University of Bonn and offers a stimulating research environment through its international network, workshops and conferences, data service, project support, research visits and doctoral program. IZA engages in (i) original and internationally competitive research in all fields of labor economics, (ii) development of policy concepts, and (iii) dissemination of research results and concepts to the interested public.

IZA Discussion Papers often represent preliminary work and are circulated to encourage discussion. Citation of such a paper should account for its provisional character. A revised version may be available directly from the author. 
IZA Discussion Paper No. 8981

April 2015

\section{ABSTRACT \\ The Rise of Female Entrepreneurs: New Evidence on Gender Differences in Liquidity Constraints}

Small business activity and female entrepreneurship have become increasingly important features of the UK economy since the start of the Great Recession. In this paper, we reexamine the impact of liquidity constraints on new business formation in an instrumental variables framework, using a previously unexplored data set from the UK. The new results indicate that it is primarily single women that drive the well-established empirical relationship between personal wealth and business start-ups. Therefore, public policies specifically targeted at relieving the liquidity constraints of women could help further accelerate the rise of female entrepreneurship.

JEL Classification: J23, L26, M13

Keywords: entrepreneurship, liquidity constraints

Corresponding author:

Tanya Wilson

Department of Economics

Royal Holloway, University of London (RHUL)

Egham TW20 0EX

United Kingdom

E-mail: tanya.wilson.2011@rhul.ac.uk 


\section{Introduction}

Small business activity and female entrepreneurship have become increasingly important features of the UK economy since the start of the Great Recession. Small firms in the UK currently account for $48 \%$ of all private sector employment, and the increase in employment since 2008 has been mostly driven by self-employment (Office of National Statistics, 2014). Although men comprise approximately two thirds of self-employed individuals, sharp gender-differences in entry into self-employment have emerged. Over the period 2009-2014 the number of self-employed women increased by a remarkable $34 \%$. In comparison, the rate of increase amongst men is less than half, reaching approximately $15 \%$.

In this paper, we examine the impact of liquidity constraints on new business formation using a previously unexplored dataset, the UK Wealth and Assets Survey. Consistent with the literature on liquidity constraints (see the review in Fairlie and Krashinsky (2012)), we find that liquidity constraints are likely to be present. However, in contrast to virtually the entire literature, we explicitly focus on the importance of gender heterogeneity and household composition in driving the overall relationship. These previously overlooked dimensions provide new results with important policy implications.

The results of instrumental variables regressions, using inheritances as an instrument, indicate that it is primarily single women that drive the well-established empirical relationship between personal wealth and business start-ups. This new finding is detectable both because of the unusually large number of female entrepreneurs in the data, and the ability to use a broader definition for an entrepreneur. Individuals are classified as entrepreneurs if they have started a business, in contrast to just being self-employed. Self-employment is the most common definition of entrepreneurship in the literature. The data source also permits separation of financial constraints (liquidity) from the broader wealth measures commonly used in the literature.

Our estimates suggest both significant and economically important impacts of financial constraints on new business formation amongst single women. In our most favoured specification, relaxation of financial constraints by $£ 1,000$ for single women results in an $8.5 \%$ increase in the probability of starting a business relative to the sample mean. Our results are robust to a range of specifications and the use of future inheritances. That is, future inheritances do not have a substantial effect on past business start-ups, increasing confidence in the validity of the instrument.

Our findings have important policy implications. Although the rate of entry into entrepreneurship is double for women compared to men, the proportion of women applying for governmentfunded business start-up support is half of that for men. This suggests that a policy aimed specifically to meet the needs of would-be female entrepreneurs, similar to the targeting that exists for ex-military personnel in the UK, could help further accelerate the rise of female entrepreneurship. 
The remainder of the paper is structured as follows: Section 2 places our study and its contribution in context. Section 3 describes the new data used in our analysis. Section 4 specifies the instrumental variables approach. Section 5 presents the IV results. Section 6 discusses the implications of the results. Section 7 concludes.

\section{Background}

While there is a vast literature examining the effect of liquidity constraints on new business formation, the importance of gender differences has not been extensively studied. For example, the seminal papers by Evans and Leighton (1989) and Evans and Jovanovic (1989) analyse the self-employment decisions of a sample of white men only. Typically, the restriction to men has been due to relatively small numbers of female self-employed.

Focusing on white men in the National Longitudinal Study of Young Men (NLSYM), the main finding in Evans and Leighton (1989) is that men with greater assets are more likely to switch into self-employment. Using the same data, Evans and Jovanovic (1989) observe that wealthier people are more inclined to become entrepreneur, and they formally explore whether liquidity constraints hinder individuals from starting a business. They develop a model of entrepreneurial choice and parameterise the tightness of the liquidity constraint. This produces a positive correlation between the probability of starting a business and net family assets, but only if liquidity constraints are present.

Despite the robust correlation between individual wealth and new business formation, identification problems remain. For example, it may be the case that would-be entrepreneurs save before starting an enterprise, implying that there would be a positive correlation between assets and business start-ups even in the absence of financial constraints. A similar correlation would arise if many family firms were inherited. To better ascertain whether financial constraints are a binding impediment to starting a business it is necessary to observe individuals who have received an exogenous wealth shock. The wealth shock can then be tied to subsequent entrepreneurial activity.

Blanchflower and Oswald (1998) proposed using inheritances and gifts as proxies for exogenous wealth shocks. Using longitudinal data from two waves of the National Child Development Study (NCDS), they use inheritances and gifts as instruments and find that those who receive windfall income are more likely to run a business. They argue that the results are not driven by direct inheritance of the business. Their results are similar when they only consider inheritances received more than three years prior to starting self-employment. Although a female dummy variable is included in the analysis, the study does not focus on potentially important interactions. 


\section{Data}

The Office of National Statistics launched the Wealth and Assets Survey (WAS) in 2006 in response to a need for a representative source of statistics on the wealth of households and individuals. The broad aim of the survey was to gather detailed information on the level and type of assets, liabilities and attitudes towards financial planning held by private individuals and households, as well as how these change over time.

Initially the survey was designed to be longitudinal with biennial interviews, and newly formed households would be added to the panel in the case of between-wave household dissolution. However, due to the extensive nature of the WAS questionnaire, which requires a substantial time commitment from respondents, it was found that the attrition rate in the WAS is higher than in other household longitudinal surveys.

Each wave of the WAS contains interviews conducted over a two-year period. The first wave commenced in July 2006 with the final interview conducted in June 2008; the second and third waves ran respectively between July 2008 - June 2010 and July 2010 - June 2012. At the time of writing, the data from the fourth wave conducted between July 2012 and June 2014 has not been released for analysis.

For the initial sample, households were drawn at random from the Royal Mail's postcode address file using a multistage sampling design: for each year 1,200 postcode sectors were drawn with the probability that an individual sector is selected being proportional to the number of unique addresses within each sector. At the second stage 26 addresses were randomly chosen from each postcode sector. Addresses were matched to HMRC data to allow for oversampling of high wealth households, as a higher rate of non-response was expected for this group. The month of interview for each household was randomly allocated over the 2-year period of fieldwork in order to achieve a proportional balance of addresses over time and geography.

The first wave achieved a response rate of 30,600 households, with 53,300 individual responses. In the second wave 32,200 questionnaires were issued, but received a response rate of only 20,000 households and 34,500 adults. Due to the high attrition rate 12,000 and 8,000 addresses

were added to the survey in waves 3 and 4 respectively, using the same multistage sampling design.

A key advantage of the WAS for our analysis is that respondents are also asked detailed questions on their main employment activity. For those reporting self-employment the date at which the self-employment spell started is recorded. In addition individuals are asked about any businesses in which they have an owning interest, including the date that each business started, the type of funds used to start the business and the size of the business, measured by the number of employees. This level of detail information regarding businesses and wealth measures in a single source is unique to the WAS, and to our knowledge has not yet been explored. 


\subsection{Descriptive Statistics}

Respondents are asked about their current main employment, and for those reporting selfemployment, the date that at which the spell began. Therefore unlike previous work that has relied on observing individuals in longitudinal data to identify an entry to self-employment (e.g. Evans and Leighton (1989) and Taylor (2001)) we calculate transitions into self-employment directly using the date of the interview and the date that the self-employment spell started. Furthermore, respondents are asked to provide information regarding other businesses for which they have an owning interest, including the date the business started ${ }^{1}$. We therefore define several measures of entry to entrepreneurship: whether an individual has started self-employment within 2 years prior to the interview date, whether an individual has started a business within the past two years, and a composite measure combining both self-employment and business starts.

We construct three distinct wealth measures from the data: liquidity, property and total wealth. Liquidity comprises financial assets (bank/savings account balances and formal financial instruments such as gilts, bonds, stocks and shares) less liabilities (loans, arrears, hire purchase). These are calculated at the individual level, and those with joint accounts are assigned equal shares of the balances. Property wealth, defined as the net value of the residence (current value less outstanding mortgages), is calculated at the household level.

Total wealth cumulates liquidity and property wealth, and additionally incorporates the value of personal and household physical assets, such as jewelery, household goods and motor vehicles. Following Disney and Gathergood (2009) we do not include pensions in the calculation of total wealth, as these are by nature illiquid and cannot be used as collateral. Respondents are asked to report the value of any inheritances over $£ 1,000$ received in the last 5 years ${ }^{2}$. All financial measures are expressed in 2010 prices.

Table 1 displays demographics of the WAS sample by gender and household composition, where we contrast single individuals and dual households by partner status rather than marital status ${ }^{3}$. There are certain notable differences in the employment measures: $10.9 \%$ of individuals report self-employment as their employment status, and $9.8 \%$ report owning (at least) one business. The composite measure indicates that $13.8 \%$ of individuals have an entrepreneurial enterprise.

We note that reported self-employment in the main job therefore captures only $75-80 \%$ of all entrepreneurial activity, and entry to self-employment constitutes only $62 \%$ of entrepreneurial

\footnotetext{
${ }^{1}$ The specific questions are "In which year did you start working continuously as a self-employed person?" for those individuals reporting self-employment as their main employment status and "In what year did you start or acquire this business?" for individuals reporting ownership of a business

${ }^{2}$ The questions are "In the last five years, that is since (date), have you personally received an inheritance valued at 1,000 or more, that is in money, property, or goods of any kind?" and "What was the total value, at that time, of everything you inherited, after tax and other deductions?"

${ }^{3}$ Of the dual households we observe, $80.6 \%$ report being married, $18.9 \%$ are cohabitating couples, $0.5 \%$ are civil partnerships/same-sex partnerships.
} 
Table 1: Descriptive Statistics

\begin{tabular}{|c|c|c|c|c|c|c|c|c|c|}
\hline & \multicolumn{3}{|c|}{ All individuals } & \multicolumn{3}{|c|}{ Single individuals } & \multicolumn{3}{|c|}{$\underline{\text { Partnered individuals }}$} \\
\hline & All & Men & Women & All & Men & Women & All & Men & Women \\
\hline \multicolumn{10}{|c|}{ Employment Measures } \\
\hline S/e Main Job & $\begin{array}{l}0.109 \\
(0.31)\end{array}$ & $\begin{array}{l}0.156 \\
(0.36)\end{array}$ & $\begin{array}{l}0.071 \\
(0.26)\end{array}$ & $\begin{array}{l}0.085 \\
(0.28)\end{array}$ & $\begin{array}{l}0.131 \\
(0.34)\end{array}$ & $\begin{array}{l}0.058 \\
(0.23)\end{array}$ & $\begin{array}{l}0.116 \\
(0.32)\end{array}$ & $\begin{array}{l}0.162 \\
(0.37)\end{array}$ & $\begin{array}{c}0.075 \\
(0.264)\end{array}$ \\
\hline Owns Business & $\begin{array}{l}0.098 \\
(0.30)\end{array}$ & $\begin{array}{l}0.147 \\
(0.35)\end{array}$ & $\begin{array}{l}0.058 \\
(0.24)\end{array}$ & $\begin{array}{l}0.067 \\
(0.25)\end{array}$ & $\begin{array}{l}0.104 \\
(0.31)\end{array}$ & $\begin{array}{l}0.044 \\
(0.21)\end{array}$ & $\begin{array}{l}0.107 \\
(0.31)\end{array}$ & $\begin{array}{l}0.157 \\
(0.36)\end{array}$ & $\begin{array}{l}0.063 \\
(0.24)\end{array}$ \\
\hline $\mathrm{S} / \mathrm{e}$ in Any Job & $\begin{array}{l}0.138 \\
(0.35)\end{array}$ & $\begin{array}{l}0.194 \\
(0.40)\end{array}$ & $\begin{array}{l}0.093 \\
(0.29)\end{array}$ & $\begin{array}{l}0.105 \\
(0.31)\end{array}$ & $\begin{array}{l}0.157 \\
(0.36)\end{array}$ & $\begin{array}{l}0.073 \\
(0.26)\end{array}$ & $\begin{array}{l}0.148 \\
(0.36)\end{array}$ & $\begin{array}{l}0.203 \\
(0.40)\end{array}$ & $\begin{array}{l}0.100 \\
(0.30)\end{array}$ \\
\hline S/e (Main) starter & $\begin{array}{l}0.026 \\
(0.16)\end{array}$ & $\begin{array}{l}0.034 \\
(0.18)\end{array}$ & $\begin{array}{l}0.019 \\
(0.14)\end{array}$ & $\begin{array}{l}0.021 \\
(0.14)\end{array}$ & $\begin{array}{l}0.027 \\
(0.16)\end{array}$ & $\begin{array}{l}0.018 \\
(0.13)\end{array}$ & $\begin{array}{l}0.027 \\
(0.16)\end{array}$ & $\begin{array}{l}0.036 \\
(0.19)\end{array}$ & $\begin{array}{l}0.019 \\
(0.14)\end{array}$ \\
\hline Business starter & $\begin{array}{l}0.039 \\
(0.20)\end{array}$ & $\begin{array}{l}0.052 \\
(0.22)\end{array}$ & $\begin{array}{l}0.029 \\
(0.17)\end{array}$ & $\begin{array}{l}0.031 \\
(0.17)\end{array}$ & $\begin{array}{l}0.040 \\
(0.20)\end{array}$ & $\begin{array}{l}0.026 \\
(0.16)\end{array}$ & $\begin{array}{l}0.042 \\
(0.20)\end{array}$ & $\begin{array}{l}0.055 \\
(0.23)\end{array}$ & $\begin{array}{l}0.030 \\
(0.17)\end{array}$ \\
\hline S/e (Any) starter & $\begin{array}{l}0.042 \\
(0.20)\end{array}$ & $\begin{array}{l}0.055 \\
(0.23)\end{array}$ & $\begin{array}{l}0.031 \\
(0.17)\end{array}$ & $\begin{array}{l}0.033 \\
(0.18)\end{array}$ & $\begin{array}{l}0.042 \\
(0.20)\end{array}$ & $\begin{array}{l}0.028 \\
(0.16)\end{array}$ & $\begin{array}{l}0.044 \\
(0.21)\end{array}$ & $\begin{array}{l}0.058 \\
(0.23)\end{array}$ & $\begin{array}{l}0.032 \\
(0.18)\end{array}$ \\
\hline \multicolumn{10}{|l|}{ Demographics } \\
\hline Age & $\begin{array}{c}43.49 \\
(10.25)\end{array}$ & $\begin{array}{l}44.00 \\
(10.01)\end{array}$ & $\begin{array}{c}43.08 \\
(10.42)\end{array}$ & $\begin{array}{c}42.76 \\
(10.78)\end{array}$ & $\begin{array}{c}43.14 \\
(10.83)\end{array}$ & $\begin{array}{l}42.53 \\
(10.74)\end{array}$ & $\begin{array}{c}43.71 \\
(10.07)\end{array}$ & $\begin{array}{l}44.20 \\
(9.79)\end{array}$ & $\begin{array}{l}43.27 \\
(10.30)\end{array}$ \\
\hline UK born & $\begin{array}{l}0.640 \\
(0.48)\end{array}$ & $\begin{array}{l}0.647 \\
(0.48)\end{array}$ & $\begin{array}{l}0.635 \\
(0.48)\end{array}$ & $\begin{array}{l}0.656 \\
(0.48)\end{array}$ & $\begin{array}{l}0.665 \\
(0.47)\end{array}$ & $\begin{array}{l}0.650 \\
(0.48)\end{array}$ & $\begin{array}{l}0.636 \\
(0.48)\end{array}$ & $\begin{array}{l}0.643 \\
(0.48)\end{array}$ & $\begin{array}{l}0.629 \\
(0.48)\end{array}$ \\
\hline White & $\begin{array}{l}0.885 \\
(0.32)\end{array}$ & $\begin{array}{l}0.885 \\
(0.32)\end{array}$ & $\begin{array}{l}0.886 \\
(0.32)\end{array}$ & $\begin{array}{l}0.898 \\
(0.30)\end{array}$ & $\begin{array}{l}0.916 \\
(0.28)\end{array}$ & $\begin{array}{l}0.888 \\
(0.32)\end{array}$ & $\begin{array}{l}0.882 \\
(0.32)\end{array}$ & $\begin{array}{l}0.877 \\
(0.33)\end{array}$ & $\begin{array}{l}0.886 \\
(0.32)\end{array}$ \\
\hline Religious & $\begin{array}{l}0.797 \\
(0.40)\end{array}$ & $\begin{array}{l}0.774 \\
(0.42)\end{array}$ & $\begin{array}{l}0.816 \\
(0.39)\end{array}$ & $\begin{array}{l}0.750 \\
(0.43)\end{array}$ & $\begin{array}{l}0.709 \\
(0.45)\end{array}$ & $\begin{array}{l}0.776 \\
(0.42)\end{array}$ & $\begin{array}{l}0.811 \\
(0.39)\end{array}$ & $\begin{array}{l}0.789 \\
(0.41)\end{array}$ & $\begin{array}{l}0.830 \\
(0.38)\end{array}$ \\
\hline D'dent Children & $\begin{array}{l}0.483 \\
(0.50)\end{array}$ & $\begin{array}{l}0.457 \\
(0.50)\end{array}$ & $\begin{array}{l}0.504 \\
(0.50)\end{array}$ & $\begin{array}{l}0.320 \\
(0.47)\end{array}$ & $\begin{array}{l}0.068 \\
(0.25)\end{array}$ & $\begin{array}{l}0.472 \\
(0.50)\end{array}$ & $\begin{array}{l}0.531 \\
(0.50)\end{array}$ & $\begin{array}{l}0.549 \\
(0.50)\end{array}$ & $\begin{array}{l}0.515 \\
(0.50)\end{array}$ \\
\hline Owns Home & $\begin{array}{l}0.727 \\
(0.45)\end{array}$ & $\begin{array}{l}0.742 \\
(0.44)\end{array}$ & $\begin{array}{l}0.715 \\
(0.45)\end{array}$ & $\begin{array}{l}0.472 \\
(0.50)\end{array}$ & $\begin{array}{l}0.510 \\
(0.50)\end{array}$ & $\begin{array}{l}0.448 \\
(0.50)\end{array}$ & $\begin{array}{l}0.802 \\
(0.40)\end{array}$ & $\begin{array}{l}0.797 \\
(0.40)\end{array}$ & $\begin{array}{l}0.807 \\
(0.39)\end{array}$ \\
\hline \multicolumn{10}{|c|}{ Financial Measures } \\
\hline Liquidity & $\begin{array}{c}11,711 \\
(23,580)\end{array}$ & $\begin{array}{c}12,743 \\
(24,714)\end{array}$ & $\begin{array}{c}10,876 \\
(22,587)\end{array}$ & $\begin{array}{c}8,643 \\
(21,382)\end{array}$ & $\begin{array}{c}11,768 \\
(24,169)\end{array}$ & $\begin{array}{c}6,753 \\
(19,262)\end{array}$ & $\begin{array}{c}12,614 \\
(24,114)\end{array}$ & $\begin{array}{c}12,974 \\
(24,836)\end{array}$ & $\begin{array}{l}12,297 \\
(23457\end{array}$ \\
\hline Property & $\begin{array}{c}113,814 \\
(110,452)\end{array}$ & $\begin{array}{c}114,139 \\
(109,530)\end{array}$ & $\begin{array}{c}113,540 \\
(111,227)\end{array}$ & $\begin{array}{c}66,077 \\
(90,727)\end{array}$ & $\begin{array}{c}68,562 \\
(91,156)\end{array}$ & $\begin{array}{c}64,505 \\
(90,424)\end{array}$ & $\begin{array}{c}127,958 \\
(111,805)\end{array}$ & $\begin{array}{c}125,063 \\
(110,741)\end{array}$ & $\begin{array}{c}130,621 \\
(112,711)\end{array}$ \\
\hline Total Wealth & $\begin{array}{c}358,035 \\
(342,167)\end{array}$ & $\begin{array}{c}360,922 \\
(340,305)\end{array}$ & $\begin{array}{c}355,569 \\
(343,735)\end{array}$ & $\begin{array}{c}199,811 \\
(259,885)\end{array}$ & $\begin{array}{c}218,140 \\
(278,592)\end{array}$ & $\begin{array}{c}187,846 \\
(246,190)\end{array}$ & $\begin{array}{c}403,952 \\
(349,403)\end{array}$ & $\begin{array}{c}395,040 \\
(344,821)\end{array}$ & $\begin{array}{c}412,168 \\
(353,382)\end{array}$ \\
\hline $\mathrm{N}$ & 38,027 & 17,215 & 20,812 & 9,045 & 3,529 & 5,516 & 28,982 & 13,686 & 15,296 \\
\hline NT & 65,376 & 29,235 & 36,141 & 14,861 & 5,599 & 9,262 & 50,515 & 23,636 & 26,879 \\
\hline
\end{tabular}

Notes: The table shows the sample means of variables used in the analysis by gender and household composition. Standard deviations are reported in parentheses.

start-ups. The self-employment rates for men are approximately double of that of women, and individuals in dual households are more likely to be self-employed that those in single households. Similarly the proportion of individuals who have started self-employment or a business in the previous two years is higher for men as compared to women, and for individuals in dual as opposed to single households.

Single women are more likely to have dependent children than single men, but there are no significant differences in age, ethnicity, nationality across sub-samples. Individuals in single households are less likely than partnered individuals to own their residence, with a lower rate of home ownership for single women as opposed to single men. This is suggestive of key differences with regard to wealth measures, confirmed by substantial differences in financial measures across 
gender and household composition. Dual households hold more wealth across all three measures than single households, and single men higher values than single women.

This is further evidenced when we examine the full distribution of each of the financial variables rather than just the sample means. We see that single women in particular are wealth constrained in comparison to both single men and all individuals in dual households, most noticeably in the liquidity measure.

Figure 1: Distribution of wealth measures

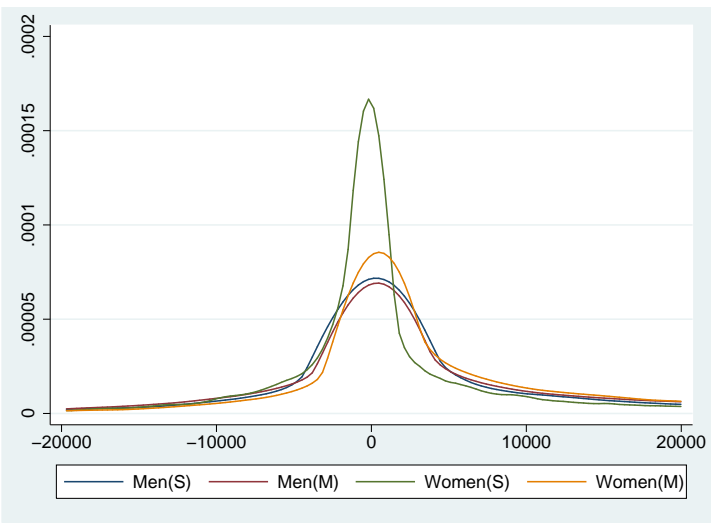

(a) Liquidity

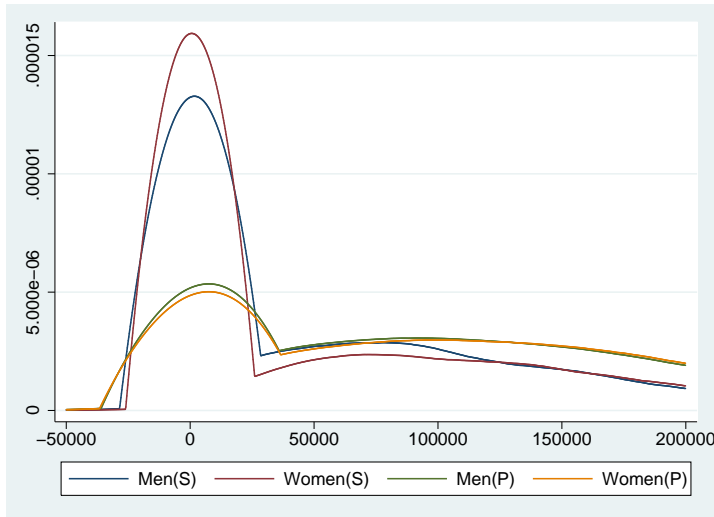

(b) Main Property

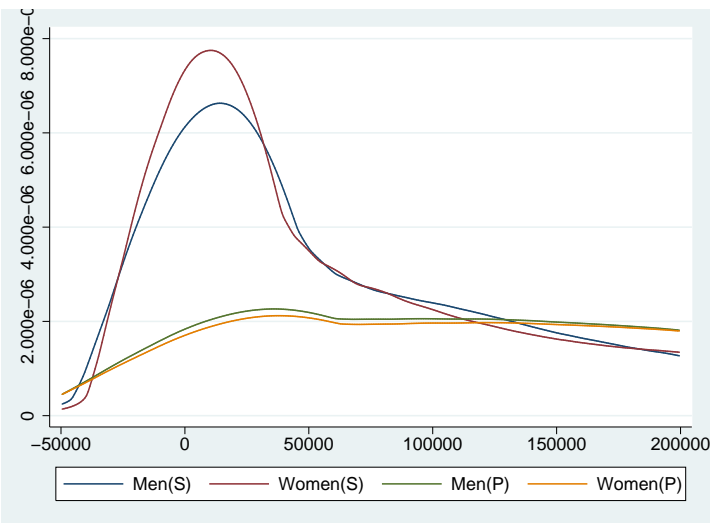

(c) Total Wealth

Notes: The graphs show the distributions of three wealth measures, (a) Liquidity, (b) Net value of main property, (c) Total wealth, as described in Section 3.1 for single men, single women, partnered men and partnered women.

\subsection{OLS estimation}

OLS estimates of the impact of each of the wealth measures on the entry to entrepreneurship are presented in Table 2. All specifications include demographic, year and area controls and include heteroskedasticity-robust standard errors, clustered by individual.

Consistent with Evans and Jovanovic (1989), we find that entry to entrepreneurship is positively related to wealth, but notably the coefficients for self-employment starts in the main job are 
markedly smaller in magnitude than business starts or the composite measure, which both produce similar estimates. However the coefficients suggest that the relationship is quantitatively small, a $£ 1,000$ increase in liquidity increases the probability that an individual has transitioned to the broad measure of entrepreneurship by 0.02 percentage points, or $0.48 \%$ relative to the sample mean. The corresponding impacts for property and total wealth are respectively $0.17 \%$ and $0.13 \%$ relative to the sample mean. The OLS estimates thus suggest that a substantial positive wealth shock would be required to have an economically meaningful impact. For liquidity we observe both gender and household composition differences: the estimates for females is approximately double of that for men, and the impact for single individuals, specifically single females, is higher than that for men. With the more illiquid wealth measures we note that there is little gender heterogeneity but differences according to household composition remain, with the impact for single individuals higher than partnered individuals.

Table 2: OLS results

\begin{tabular}{|c|c|c|c|c|c|c|c|c|c|}
\hline & $\begin{array}{l}(1) \\
\text { Main }\end{array}$ & $\begin{array}{c}\text { Liquidity } \\
(2) \\
\text { Bus }\end{array}$ & $\begin{array}{l}(3) \\
\text { Any }\end{array}$ & $\begin{array}{c}(4) \\
\text { Main }\end{array}$ & $\begin{array}{c}\text { Iain Prope } \\
(5) \\
\text { Bus }\end{array}$ & $\begin{array}{l}(6) \\
\text { Any }\end{array}$ & $\begin{array}{l}(7) \\
\text { Main }\end{array}$ & $\begin{array}{c}\text { Total Wealt } \\
(8) \\
\text { Bus }\end{array}$ & $\begin{array}{l}(9) \\
\text { Any }\end{array}$ \\
\hline \multicolumn{10}{|l|}{ Panel A } \\
\hline All individuals & $\begin{array}{l}0.00005 \\
(0.0000)\end{array}$ & $\begin{array}{l}0.00019^{* * *} \\
\quad(0.0000)\end{array}$ & $\begin{array}{c}0.00020^{* * * *} \\
(0.0000)\end{array}$ & $\begin{array}{c}0.00003^{* * *} \\
(0.0000)\end{array}$ & $\begin{array}{c}0.00006^{* * *} \\
(0.0000)\end{array}$ & $\begin{array}{c}0.00007^{* * *} \\
(0.0000)\end{array}$ & $\begin{array}{c}0.00002^{* * *} \\
(0.0000)\end{array}$ & $\begin{array}{l}0.00005^{* * *} \\
(0.0000)\end{array}$ & $\begin{array}{c}0.00005^{* * *} \\
(0.0000)\end{array}$ \\
\hline $\mathrm{N}$ & 65,349 & 65,349 & 65,349 & 66,277 & 66,277 & 66,277 & 65,352 & 65,352 & 65,352 \\
\hline Males & $\begin{array}{c}-0.00000 \\
(0.0000)\end{array}$ & $\begin{array}{l}0.00010 \\
(0.0001)\end{array}$ & $\begin{array}{c}0.00013^{* *} \\
(0.0001)\end{array}$ & $\begin{array}{l}0.00002 \\
(0.0000)\end{array}$ & $\begin{array}{c}0.00006^{* * *} \\
(0.0000)\end{array}$ & $\begin{array}{c}0.00007^{* * *} \\
(0.0000)\end{array}$ & $\begin{array}{c}0.00002^{* * *} \\
(0.0000)\end{array}$ & $\begin{array}{c}0.00004^{* * *} \\
(0.0000)\end{array}$ & $\begin{array}{c}0.00005^{* * *} \\
(0.0000)\end{array}$ \\
\hline $\mathrm{N}$ & 29,221 & 29,221 & 29,221 & 30,367 & 30,367 & 30,367 & 29,961 & 29,961 & 29,961 \\
\hline Females & $\begin{array}{c}0.00010^{* *} \\
(0.0000)\end{array}$ & $\begin{array}{c}0.00028^{* * *} \\
(0.0001)\end{array}$ & $\begin{array}{c}0.00028^{* * *} \\
(0.0001)\end{array}$ & $\begin{array}{c}0.00003^{* * *} \\
(0.0000)\end{array}$ & $\begin{array}{c}0.00007^{* * *} \\
(0.0000)\end{array}$ & $\begin{array}{c}0.00008^{* * *} \\
(0.0000)\end{array}$ & $\begin{array}{c}0.00002^{* * *} \\
(0.0000)\end{array}$ & $\begin{array}{c}0.00005^{* * *} \\
(0.0000)\end{array}$ & $\begin{array}{c}0.00006^{* * *} \\
(0.0000)\end{array}$ \\
\hline$N$ & 36,128 & 36,128 & 36,128 & 35,910 & 35,910 & 35,910 & 35,391 & 35,391 & 35,391 \\
\hline \multicolumn{10}{|l|}{ Panel B } \\
\hline Single Males & $\begin{array}{l}0.00007 \\
(0.0001)\end{array}$ & $\begin{array}{l}0.00018 \\
(0.0001)\end{array}$ & $\begin{array}{c}0.00024^{*} \\
(0.0001)\end{array}$ & $\begin{array}{l}0.00003 \\
(0.0000)\end{array}$ & $\begin{array}{c}0.00010^{* *} \\
(0.0000)\end{array}$ & $\begin{array}{c}0.00011^{* * *} \\
(0.0000)\end{array}$ & $\begin{array}{c}0.00004^{* *} \\
(0.0000)\end{array}$ & $\begin{array}{l}0.00006^{* * *} \\
(0.0000)\end{array}$ & $\begin{array}{c}0.00008^{* * *} \\
(0.0000)\end{array}$ \\
\hline $\mathrm{N}$ & 5,592 & 5,592 & 5,592 & 5,867 & 5,867 & 5,867 & 5,863 & 5,863 & 5,863 \\
\hline Single Females & $\begin{array}{l}0.00014 \\
(0.0001)\end{array}$ & $\begin{array}{c}0.00036^{* * *} \\
(0.0001)\end{array}$ & $\begin{array}{c}0.00035^{* * *} \\
(0.0001)\end{array}$ & $\begin{array}{c}0.00006^{* *} \\
(0.0000)\end{array}$ & $\begin{array}{c}0.00011^{* * *} \\
(0.0000)\end{array}$ & $\begin{array}{c}0.00012^{* * *} \\
(0.0000)\end{array}$ & $\begin{array}{c}0.00004^{* * *} \\
(0.0000)\end{array}$ & $\begin{array}{c}0.00009^{* * *} \\
(0.0000)\end{array}$ & $\begin{array}{c}0.00009^{* * *} \\
(0.0000)\end{array}$ \\
\hline $\mathrm{N}$ & 9,257 & 9,257 & 9,257 & 9,276 & 9,276 & 9,276 & 9,180 & 9,180 & 9,180 \\
\hline Partnered Males & $\begin{array}{c}-0.00002 \\
(0.0001)\end{array}$ & $\begin{array}{l}0.00008 \\
(0.0001)\end{array}$ & $\begin{array}{l}0.00010 \\
(0.0001)\end{array}$ & $\begin{array}{l}0.00001 \\
(0.0000)\end{array}$ & $\begin{array}{l}0.00005^{* * *} \\
(0.0000)\end{array}$ & $\begin{array}{c}0.00006^{* * *} \\
(0.0000)\end{array}$ & $\begin{array}{c}0.00001^{*} \\
(0.0000)\end{array}$ & $\begin{array}{c}0.00004^{* * *} \\
(0.0000)\end{array}$ & $\begin{array}{c}0.00004^{* * *} \\
(0.0000)\end{array}$ \\
\hline $\mathrm{N}$ & 23,629 & 23,629 & 23,629 & 24,500 & 24,500 & 24,500 & 24,098 & 24,098 & 24,098 \\
\hline Partnered Females & $\begin{array}{c}0.00010^{* *} \\
(0.0000)\end{array}$ & $\begin{array}{c}0.00027^{* * *} \\
(0.0001)\end{array}$ & $\begin{array}{c}0.00026^{* * *} \\
(0.0001)\end{array}$ & $\begin{array}{c}0.00003^{* * *} \\
(0.0000)\end{array}$ & $\begin{array}{c}0.00007^{* * *} \\
(0.0000)\end{array}$ & $\begin{array}{c}0.00007^{* * *} \\
(0.0000)\end{array}$ & $\begin{array}{c}0.00002^{* * *} \\
(0.0000)\end{array}$ & $\begin{array}{c}0.00005^{* * *} \\
(0.0000)\end{array}$ & $\begin{array}{c}0.00005^{* * *} \\
(0.0000)\end{array}$ \\
\hline $\mathrm{N}$ & 26,871 & 26,871 & 26,871 & 26,634 & 26,634 & 26,634 & 26,211 & 26,211 & 26,211 \\
\hline $\begin{array}{l}\text { Controls: } \\
\text { Wave \& Region }\end{array}$ & Yes & Yes & Yes & Yes & Yes & Yes & Yes & Yes & Yes \\
\hline Demographics & Yes & Yes & Yes & Yes & Yes & Yes & Yes & Yes & Yes \\
\hline
\end{tabular}

Notes: The table shows OLS estimates of self-employment start in the main job, a business start or any entreneurial start within the past two years on wealth measures (in $£ 1,000$ s). Robust standard errors, clustered by individual, are reported in parentheses. ${ }^{*} p<0.05,{ }^{* *} p<0.01,{ }^{* * *} p<0.001$.

\section{Estimation Strategy}

In our main estimation framework, we consider a linear, constant-effects probability model relating whether individual $i$ has started an entrepreneurial enterprise within the past 2 years of the observation date $t, Y_{i(-2<t<0)}$, with a measure of wealth $W_{i t}$, a vector of individual 
characteristics, $X_{i t}$, an individual time-invariant effect, $\rho_{i}$, an aggregate time effect, $\eta_{t}$, and an individual-specific random error at time $t, u_{i t}$ :

$$
Y_{i(-2<t<0)}=\beta_{0}+\beta_{1} W_{i t}+\delta X_{i t}+\eta_{t}+\rho_{i}+u_{i t}
$$

Equation (1) formed the specification for the OLS estimates presented in Table 2, which confirmed a positive relationship between each of the wealth measures and the propensity for entry to entrepreneurship. However, Blanchflower and Oswald (1998) observes this relationship would arise if individuals accumulate assets prior to starting an enterprise, implying that the OLS estimate of $\beta_{1}$ does not have a causal interpretation. Following their approach we therefore consider an instrumental variables estimation:

$$
W_{i t}=\gamma_{0}+\gamma_{1} \text { inheritance }_{i(-5<t<0)}+\delta X_{i t}+\eta_{t}+\rho_{i}+\epsilon_{i t}
$$

In the first stage equation (2) we estimate the impact of inheritance receipt ${ }^{4}$ in the previous 5 years on wealth, controlling as before for observed and unobserved individual characteristics, $X_{i t}$ and $\rho_{i}$ respectively, aggregate influences that affect all individuals contemporaneously, $\eta_{t}$, and an idiosyncratic error component $\epsilon_{i t}$. As the error terms $\epsilon_{i t}$ and $u_{i t}$ may be correlated, a consistent estimate of $\beta_{1}$ is obtained by instrumenting $W_{i t}$ in the second stage with its predicted value from the first stage equation. The identifying assumption in this context is that inheritances are related to entrepreneurial entry only through their impact on wealth, implying that they are excludable in the second stage. Given the validity of our exclusion restriction ${ }^{5}, \beta_{1}^{I V}$ is interpretable as the causal effect of wealth on the propensity to start an enterprise.

\section{Results}

In Section 5.1 we present estimates from the first and second stages of the IV estimation, and examine the robustness of our results to alternative employment measures and future inheritances in Section 5.2. We offer an interpretion of our results and discuss the policy implications in Section 6.

\subsection{Main Results}

Table 3 presents the estimates of the first stage, using the specification described by equation (2) in Section 3. For each of our wealth measures, liquidity, net property value and total wealth, we present the coefficients without and with demographic controls respectively, both estimations

\footnotetext{
${ }^{4}$ Specifically we use the $\log$ amount of inheritance received, where nil inheritances are replaced with 0.1 before taking logs.

${ }^{5}$ In Section 6 we present evidence that this assumption is valid.
} 
include wave and region controls. Panel A shows the estimates for all individuals, and separately by gender, whereas panel B separates further by household composition. In all regressions we observe a sizable significant impact of past inheritances on current wealth levels. The magnitude of the impact of a $1 \%$ increase in the amount of inheritance received ranges between $£ 9.70$ and $£ 16$ for liquidity, increasing to a range of $£ 25$-£33 for net property wealth, and £72-£88 for total wealth.

Table 3: First Stage

\begin{tabular}{|c|c|c|c|c|c|c|}
\hline & \multicolumn{2}{|c|}{ Liquidity } & \multicolumn{2}{|c|}{ Main Property } & \multicolumn{2}{|c|}{ Total Wealth } \\
\hline & (1) & $(2)$ & (3) & (4) & (5) & (6) \\
\hline Panel A & & & & & & \\
\hline All Individuals & $\begin{array}{c}1.2019^{* * *} \\
(0.0627)\end{array}$ & $\begin{array}{c}1.0712^{* * *} \\
(0.0607)\end{array}$ & $\begin{array}{c}3.8257^{* * *} \\
(0.2247)\end{array}$ & $\begin{array}{c}2.8481^{* * *} \\
(0.1973)\end{array}$ & $\begin{array}{c}9.2579^{* * *} \\
(0.4488)\end{array}$ & $\begin{array}{c}7.6765^{* * *} \\
(0.3945)\end{array}$ \\
\hline $\mathrm{N}$ & 65,376 & 65,349 & 66,305 & 66,277 & 65,377 & 65,352 \\
\hline Males & $\begin{array}{c}1.2286^{* * *} \\
(0.0927)\end{array}$ & $\begin{array}{c}1.1137^{* * *} \\
(0.0903)\end{array}$ & $\begin{array}{c}3.6267^{* * *} \\
(0.3286)\end{array}$ & $\begin{array}{c}2.8156^{* * *} \\
(0.2917)\end{array}$ & $\begin{array}{c}8.8660^{* * *} \\
(0.6596)\end{array}$ & $\begin{array}{c}7.6014^{* * *} \\
(0.5851)\end{array}$ \\
\hline $\mathrm{N}$ & 29,235 & 29,221 & 30,382 & 30,367 & 29,975 & 29,961 \\
\hline Females & $\begin{array}{c}1.1818^{* * *} \\
(0.0850)\end{array}$ & $\begin{array}{c}1.0322^{* * *} \\
(0.0818)\end{array}$ & $\begin{array}{c}3.9839^{* * *} \\
(0.3074)\end{array}$ & $\begin{array}{c}2.8573^{* * *} \\
(0.2679)\end{array}$ & $\begin{array}{c}9.5534^{* * *} \\
(0.6111)\end{array}$ & $\begin{array}{c}7.6836^{* * *} \\
(0.5339)\end{array}$ \\
\hline $\mathrm{N}$ & 36,141 & 36,128 & 35,923 & 35,910 & 35,402 & 35,391 \\
\hline Panel B & & & & & & \\
\hline Single Males & $\begin{array}{c}1.7207^{* * *} \\
(0.2262)\end{array}$ & $\begin{array}{c}1.6231^{* * *} \\
(0.2244)\end{array}$ & $\begin{array}{c}3.4190^{* * *} \\
(0.5911)\end{array}$ & $\begin{array}{c}2.5201^{* * *} \\
(0.5677)\end{array}$ & $\begin{array}{c}9.0821^{* * *} \\
(1.2628)\end{array}$ & $\begin{array}{c}7.4831^{* * *} \\
(1.1558)\end{array}$ \\
\hline $\mathrm{N}$ & 5,599 & 5,592 & 5,874 & 5,867 & 5,870 & 5,863 \\
\hline Single Females & $\begin{array}{c}1.3597^{* * *} \\
(0.1643)\end{array}$ & $\begin{array}{c}1.1992^{* * *} \\
(0.1597)\end{array}$ & $\begin{array}{c}4.4896^{* * *} \\
(0.5397)\end{array}$ & $\begin{array}{c}3.2800^{* * *} \\
(0.4935)\end{array}$ & $\begin{array}{c}10.5710^{* * *} \\
(1.0729)\end{array}$ & $\begin{array}{c}8.7727^{* * *} \\
(0.9878)\end{array}$ \\
\hline $\mathrm{N}$ & 9,262 & 9,257 & 9,281 & 9,276 & 9,184 & 9,180 \\
\hline Partnered Males & $\begin{array}{c}1.1052^{* * *} \\
(0.1007)\end{array}$ & $\begin{array}{c}0.9858^{* * *} \\
(0.0974)\end{array}$ & $\begin{array}{c}3.8164^{* * *} \\
(0.3754)\end{array}$ & $\begin{array}{c}2.9697^{* * *} \\
(0.3345)\end{array}$ & $\begin{array}{c}9.2451^{* * *} \\
(0.7344)\end{array}$ & $\begin{array}{c}7.8144^{* * *} \\
(0.6678)\end{array}$ \\
\hline $\mathrm{N}$ & 23,636 & 23,629 & 24,508 & 24,500 & 24,105 & 24,098 \\
\hline Partnered Females & $\begin{array}{c}1.1134^{* * *} \\
(0.0985)\end{array}$ & $\begin{array}{c}0.9704^{* * *} \\
(0.0949)\end{array}$ & $\begin{array}{c}3.6710^{* * *} \\
(0.3548)\end{array}$ & $\begin{array}{c}2.6770^{* * *} \\
(0.3143)\end{array}$ & $\begin{array}{c}9.0174^{* * *} \\
(0.6982)\end{array}$ & $\begin{array}{c}7.2467^{* * *} \\
(0.6273)\end{array}$ \\
\hline $\mathrm{N}$ & 26,879 & 26,871 & 26,642 & 26,634 & 26,218 & 26,211 \\
\hline Wave \& Region controls & Yes & Yes & Yes & Yes & Yes & Yes \\
\hline Demographic controls & No & Yes & No & Yes & No & Yes \\
\hline
\end{tabular}

Notes: The table shows estimates of wealth measures (in $£ 1,000$ s) on the inheritance amount (in logs) received in the past 5 years as described by equation (2) in Section 4 . Robust standard errors, clustered by individual, are reported in parentheses. ${ }^{*} p<0.05,{ }^{* *} p<0.01,{ }^{* * *} p<0.001$.

The second stage estimates are presented in Table 4 for the three entry to entrepreneurship (within the two years prior to interview) variables: whether an individual has started selfemployment as their employment status (Main), whether an individual has started a business (Bus), the composite measure of either a self-employment or a business start (Any). All specifications include demographic, region and wave controls.

Considering the results first for all individuals, the estimates reveal that a $£ 1,000$ increase in wealth exerts a significant impact on entry to entrepreneurship, with the largest effect seen for financial wealth (liquidity). The impact for entry to self-employment does not achieve significance using any of the wealth measures, and is considerably smaller than that for business starts. The coefficient on the composite entry measure is not significantly different to that of business starts. The magnitude and significance of these results predominantly reflect the re- 
Table 4: IV results

\begin{tabular}{|c|c|c|c|c|c|c|c|c|c|}
\hline & \multicolumn{3}{|c|}{ Liquidity } & \multicolumn{3}{|c|}{ Main Property } & \multicolumn{3}{|c|}{ Total Wealth } \\
\hline & (1) & $(2)$ & (3) & (4) & (5) & (6) & (7) & (8) & $(9)$ \\
\hline & Main & Bus & Any & Main & Bus & Any & Main & Bus & Any \\
\hline \multicolumn{10}{|l|}{ Panel A } \\
\hline \multirow[t]{2}{*}{ All individuals } & 0.0004 & $0.0009^{* *}$ & $0.0008^{* *}$ & 0.0002 & $0.0003^{* *}$ & $0.0004^{* *}$ & 0.0001 & $0.0001^{* *}$ & $0.0001^{* *}$ \\
\hline & $(0.0003)$ & $(0.0004)$ & $(0.0004)$ & $(0.0001)$ & $(0.0001)$ & $(0.0002)$ & $(0.0000)$ & $(0.0001)$ & $(0.0001)$ \\
\hline $\mathrm{N}$ & 65.349 & 65.349 & 65.349 & 66,277 & 66,277 & 66,277 & 65,352 & 65,352 & 65,352 \\
\hline First stage F-test & 310.92 & 310.92 & 310.92 & 208.37 & 208.37 & 208.37 & 378.63 & 378.63 & 378.63 \\
\hline \multirow[t]{2}{*}{ Males } & 0.0003 & 0.0006 & 0.0005 & 0.0002 & 0.0002 & 0.0003 & 0.0001 & 0.0001 & 0.0001 \\
\hline & $(0.0005)$ & $(0.0006)$ & $(0.0007)$ & $(0.0002)$ & $(0.0002)$ & $(0.0003)$ & $(0.0001)$ & $(0.0001)$ & $(0.0001)$ \\
\hline $\mathrm{N}$ & 29,221 & 29,221 & 29,221 & 30,367 & 30,367 & 30,367 & 29,961 & 29,961 & 29,961 \\
\hline First stage F-test & 152.14 & 152.14 & 152.14 & 93.14 & 93.14 & 93.14 & 168.75 & 168.75 & 168.75 \\
\hline \multirow[t]{2}{*}{ Females } & 0.0004 & $0.0011^{* *}$ & $0.0011^{* *}$ & 0.0002 & $0.0004^{* *}$ & $0.0004^{* *}$ & 0.0001 & $0.0001^{*}$ & $0.0001^{*}$ \\
\hline & $(0.0004)$ & $(0.0005)$ & $(0.0005)$ & $(0.0001)$ & $(0.0002)$ & $(0.0002)$ & $(0.0000)$ & $(0.0001)$ & $(0.0001)$ \\
\hline $\mathrm{N}$ & 36,128 & 36,128 & 36,128 & 35,910 & 35,910 & 35,910 & 35,391 & 35,391 & 35,391 \\
\hline First stage F-test & 159.06 & 159.06 & 159.06 & 113.78 & 113.78 & 113.78 & 207.08 & 207.08 & 207.08 \\
\hline \multicolumn{10}{|l|}{ Panel B } \\
\hline \multirow[t]{2}{*}{ Single Males } & 0.0003 & 0.0001 & -0.0000 & 0.0006 & 0.0004 & 0.0004 & 0.0002 & 0.0001 & 0.0001 \\
\hline & $(0.0007)$ & $(0.0008)$ & $(0.0008)$ & $(0.0005)$ & $(0.0006)$ & $(0.0006)$ & $(0.0002)$ & $(0.0002)$ & $(0.0002)$ \\
\hline $\mathrm{N}$ & 5,592 & 5,592 & 5,592 & 5,867 & 5,867 & 5,867 & 5,863 & 5,863 & 5,863 \\
\hline First stage F-test & 52.33 & 52.33 & 52.33 & 19.70 & 19.70 & 19.70 & 41.92 & 41.92 & 41.92 \\
\hline \multirow[t]{2}{*}{ Single Females } & 0.0012 & $0.0022^{* *}$ & $0.0023^{* *}$ & 0.0003 & $0.0007^{*}$ & $0.0007^{*}$ & 0.0001 & $0.0002^{*}$ & $0.0002^{*}$ \\
\hline & $(0.0008)$ & $(0.0011)$ & $(0.0011)$ & $(0.0003)$ & $(0.0004)$ & $(0.0004)$ & $(0.0001)$ & $(0.0001)$ & $(0.0001)$ \\
\hline $\mathrm{N}$ & 9,257 & 9,257 & 9,257 & 9,276 & 9,276 & 9,276 & 9,180 & 9,180 & 9,180 \\
\hline \multirow{2}{*}{ First stage F-test } & 56.35 & 56.35 & 56.35 & 44.17 & 44.17 & 44.17 & 78.87 & 78.87 & 78.87 \\
\hline & 0.0002 & 0.0008 & 0.0007 & 0.0001 & 0.0002 & 0.0003 & 0.0000 & 0.0001 & 0.0001 \\
\hline Par & $(0.0007)$ & $(0.0008)$ & $(0.0009)$ & $(0.0002)$ & $(0.0003)$ & $(0.0003)$ & $(0.0001)$ & $(0.0001)$ & $(0.0001)$ \\
\hline $\mathrm{N}$ & 23,629 & 23,629 & 23,629 & 24,500 & 24,500 & 24,500 & 24,098 & 24,098 & 24,098 \\
\hline \multirow{3}{*}{$\begin{array}{l}\text { First stage F-test } \\
\text { Partnered Females }\end{array}$} & 102.50 & 102.50 & 102.50 & 78.80 & 78.80 & 78.80 & 136.92 & 136.92 & 136.92 \\
\hline & 0.0002 & 0.0007 & 0.0007 & 0.0001 & 0.0003 & 0.0003 & 0.0000 & 0.0001 & 0.0001 \\
\hline & $(0.0004)$ & $(0.0006)$ & & $(0.0002)$ & $(0.0002)$ & & $(0.0001)$ & $(0.0001)$ & $(0.0001)$ \\
\hline $\mathrm{N}$ & 26,871 & 26,871 & 26,871 & 26,634 & 26,634 & 26,634 & 26,211 & 26,211 & 26,211 \\
\hline First stage F-test & 104.66 & 104.66 & 104.66 & 72.55 & 72.55 & 72.55 & 133.43 & 133.43 & 133.43 \\
\hline \multicolumn{10}{|l|}{ Controls. } \\
\hline Wave \& Region & Yes & Yes & Yes & Yes & Yes & Yes & Yes & Yes & Yes \\
\hline Demographics & Yes & Yes & Yes & Yes & Yes & Yes & Yes & Yes & Yes \\
\hline
\end{tabular}

Notes: The table shows IV estimates of self-employment start in the main job, a business start or any entreneurial start within the past two years on wealth measures (in $£ 1,000$ s) instrumented with the log of inheritance amount received in the past 5 years. Robust standard errors, clustered by individual, are reported in parentheses. ${ }^{*} p<0.05,{ }^{* *} p<0.01$, *** $p<0.001$.

sponse of females, as can be seen when we examine the impacts separately by gender. Further disaggregating the sample by household composition we see that the female results themselves are specifically driven by the estimated impact for single females.

\subsection{Robustness}

Given the first-stage estimates in Table 3 and the large reported F-statistics in Table 4 we are confident in the strength of our instrument and therefore it is not necessary to explore a Limited Information Maximum Likelihood (LIML) methodology. Instead we examine the robustness of results for alternative entry to entrepreneurship measures and to the receipt of future inheritances. 
As the enterprise start variables were calculated using year of business start and interview date we were able to exert discretion over the period for which these were defined. In contrast we had no control of the periodicity of the inheritance measure, as the date that the inheritance was received was not recorded, only whether an inheritance had been received (and its amount) in the previous 5 years. Therefore in order to capture specifically the effect of inheritances that occurred prior to entrepreneurship entry we restricted the time period for enterprise starts in the analysis to those which set up in the 2 years prior to the interview date. Table 5 compares alternative definitions of our entry measures, considering business start-ups within the past 1, 2 and 5 years on each of the wealth measures. We observe that the coefficients remain consistent with these alternate definitions of business starts.

Table 5: Comparison of measures

\begin{tabular}{|c|c|c|c|c|c|c|c|c|c|}
\hline & \multicolumn{3}{|c|}{ Liquidity } & \multicolumn{3}{|c|}{ Main Property } & \multicolumn{3}{|c|}{ Total Wealth } \\
\hline & (1) & $(2)$ & (3) & (4) & (5) & (6) & (7) & (8) & (9) \\
\hline & Within 1 & Within 2 & Within 5 & Within 1 & Within 2 & Within 5 & Within 1 & Within 2 & Within 5 \\
\hline \multicolumn{10}{|l|}{ Panel A } \\
\hline \multirow[t]{2}{*}{ All individuals } & $0.0007^{*}$ & $0.0009^{* *}$ & $0.0011^{* *}$ & $0.0003^{* *}$ & $0.0003^{* *}$ & $0.0004^{* *}$ & $0.0001^{* *}$ & $0.0001^{* *}$ & $0.0001^{* *}$ \\
\hline & $(0.0004)$ & $(0.0004)$ & $(0.0005)$ & $(0.0001)$ & $(0.0001)$ & $(0.0002)$ & $(0.0000)$ & $(0.0001)$ & $(0.0001)$ \\
\hline \multirow{2}{*}{$\begin{array}{l}\text { First stage F-test } \\
\mathrm{N}\end{array}$} & 310.92 & 310.92 & 310.92 & 208.37 & 208.37 & 208.37 & 378.63 & 378.63 & 378.63 \\
\hline & 65,349 & 65,349 & 65,349 & 66,277 & 66,277 & 66,277 & 65,352 & 65,352 & 65,352 \\
\hline \multirow[t]{2}{*}{ Males } & 0.0004 & 0.0006 & 0.0007 & 0.0001 & 0.0002 & 0.0002 & 0.0001 & 0.0001 & 0.0001 \\
\hline & $(0.0006)$ & $(0.0006)$ & $(0.0008)$ & $(0.0002)$ & $(0.0002)$ & $(0.0003)$ & $(0.0001)$ & $(0.0001)$ & $(0.0001)$ \\
\hline $\mathrm{N}$ & 29,221 & 29,221 & 29,221 & 30,367 & 30,367 & 30,367 & 29,961 & 29,961 & 29,961 \\
\hline First stage F-test & 152.14 & 152.14 & 152.14 & 93.14 & 93.14 & 93.14 & 168.75 & 168.75 & 168.75 \\
\hline \multirow[t]{2}{*}{ Females } & $0.0008^{*}$ & $0.0011^{* *}$ & $0.0015^{* *}$ & $0.0003^{* *}$ & $0.0004^{* *}$ & $0.0006^{* *}$ & $0.0001^{*}$ & $0.0001^{*}$ & $0.0002^{* *}$ \\
\hline & $(0.0005)$ & $(0.0005)$ & $(0.0006)$ & $(0.0002)$ & $(0.0002)$ & $(0.0002)$ & $(0.0001)$ & $(0.0001)$ & $(0.0001)$ \\
\hline $\mathrm{N}$ & 36,128 & 36,128 & 36,128 & 35,910 & 35,910 & 35,910 & 35,391 & 35,391 & 35,391 \\
\hline First stage F-test & 159.06 & 159.06 & 159.06 & 113.78 & 113.78 & 113.78 & 207.08 & 207.08 & 207.08 \\
\hline \multicolumn{10}{|l|}{ Panel B } \\
\hline \multirow[t]{2}{*}{ Single Males } & 0.0006 & 0.0001 & -0.0005 & 0.0006 & 0.0004 & -0.0000 & 0.0002 & 0.0001 & 0.0000 \\
\hline & $(0.0008)$ & $(0.0008)$ & $(0.0010)$ & $(0.0005)$ & $(0.0006)$ & $(0.0006)$ & $(0.0002)$ & $(0.0002)$ & $(0.0002)$ \\
\hline $\mathrm{N}$ & 5,592 & 5,592 & 5,592 & 5,867 & 5,867 & 5,867 & 5,863 & 5,863 & 5,863 \\
\hline First stage F-test & 52.33 & 52.33 & 52.33 & 19.70 & 19.70 & 19.70 & 41.92 & 41.92 & 41.92 \\
\hline \multirow[t]{2}{*}{ Single Females } & $0.0021^{* *}$ & $0.0022^{* *}$ & $0.0025^{* *}$ & $0.0007^{* *}$ & $0.0007^{*}$ & $0.0009^{* *}$ & $0.0003^{* *}$ & $0.0002^{*}$ & $0.0003^{* *}$ \\
\hline & $(0.0010)$ & $(0.0011)$ & $(0.0013)$ & $(0.0003)$ & $(0.0004)$ & $(0.0004)$ & $(0.0001)$ & $(0.0001)$ & $(0.0002)$ \\
\hline $\mathrm{N}$ & 9,257 & 9,257 & 9,257 & 9,276 & 9,276 & 9,276 & 9,180 & 9,180 & 9,180 \\
\hline & 56.35 & 56.35 & 56.35 & 44.17 & 44.17 & 44.17 & 78.87 & 78.87 & 78.87 \\
\hline \multirow[t]{2}{*}{ Partnered Males } & 0.0003 & 0.0008 & 0.0012 & 0.0000 & 0.0002 & 0.0002 & 0.0001 & 0.0001 & 0.0001 \\
\hline & $(0.0007)$ & $(0.0008)$ & $(0.0011)$ & $(0.0002)$ & $(0.0003)$ & $(0.0003)$ & $(0.0001)$ & $(0.0001)$ & $(0.0001)$ \\
\hline $\mathrm{N}$ & 23,629 & 23,629 & 23,629 & 24,500 & 24,500 & 24,500 & 24,098 & 24,098 & 24,098 \\
\hline \multirow{3}{*}{$\begin{array}{l}\text { First stage F-test } \\
\text { Partnered Females }\end{array}$} & 102.50 & 102.50 & 102.50 & 78.80 & 78.80 & 78.80 & 136.92 & 136.92 & 136.92 \\
\hline & 0.0004 & 0.0007 & 0.0012 & 0.0002 & 0.0003 & $0.0005^{*}$ & 0.0001 & 0.0001 & 0.0001 \\
\hline & $(0.0005)$ & $(0.0006)$ & $(0.0008)$ & $(0.0002)$ & $(0.0002)$ & $(0.0003)$ & $(0.0001)$ & $(0.0001)$ & $(0.0001)$ \\
\hline $\mathrm{N}$ & 26,871 & 26,871 & 26,871 & 26,634 & 26,634 & 26,634 & 26,211 & 26,211 & 26,211 \\
\hline First stage F-test & 104.66 & 104.66 & 104.66 & 72.55 & 72.55 & 72.55 & 133.43 & 133.43 & 133.43 \\
\hline \multicolumn{10}{|l|}{ Controls: 1 - } \\
\hline Wave \& Region & Yes & Yes & Yes & Yes & Yes & Yes & Yes & Yes & Yes \\
\hline Demographics & Yes & Yes & Yes & Yes & Yes & Yes & Yes & Yes & Yes \\
\hline
\end{tabular}

Notes: The table shows IV estimates of business starts within the past year, two years and 5 years on wealth measures (in $£ 1,000$ s) instrumented with the log of inheritance amount received in the past 5 years. Robust standard errors, clustered by individual, are reported in parentheses. ${ }^{*} p<0.05,{ }^{* *} p<0.01,{ }^{* * *} p<0.001$.

One important robustness check that informs us of the validity of the instrument is to ascertain whether the same results obtain when using future inheritances. The potential threat to identification is that if there is some unobserved influence implying both that wealthier people 
are more likely to obtain an inheritance and also that wealthier people are more likely to start a business then there would be a positive correlation between business starts and inheritances even in the absence of financial constraints. Disney and Gathergood (2009) in their study of self-employment entry using data from the British Household Panel Survey, found evidence that future inheritances were just as good at predicting the transition into self-employment as past inheritances.

Table 6: Future Inheritances

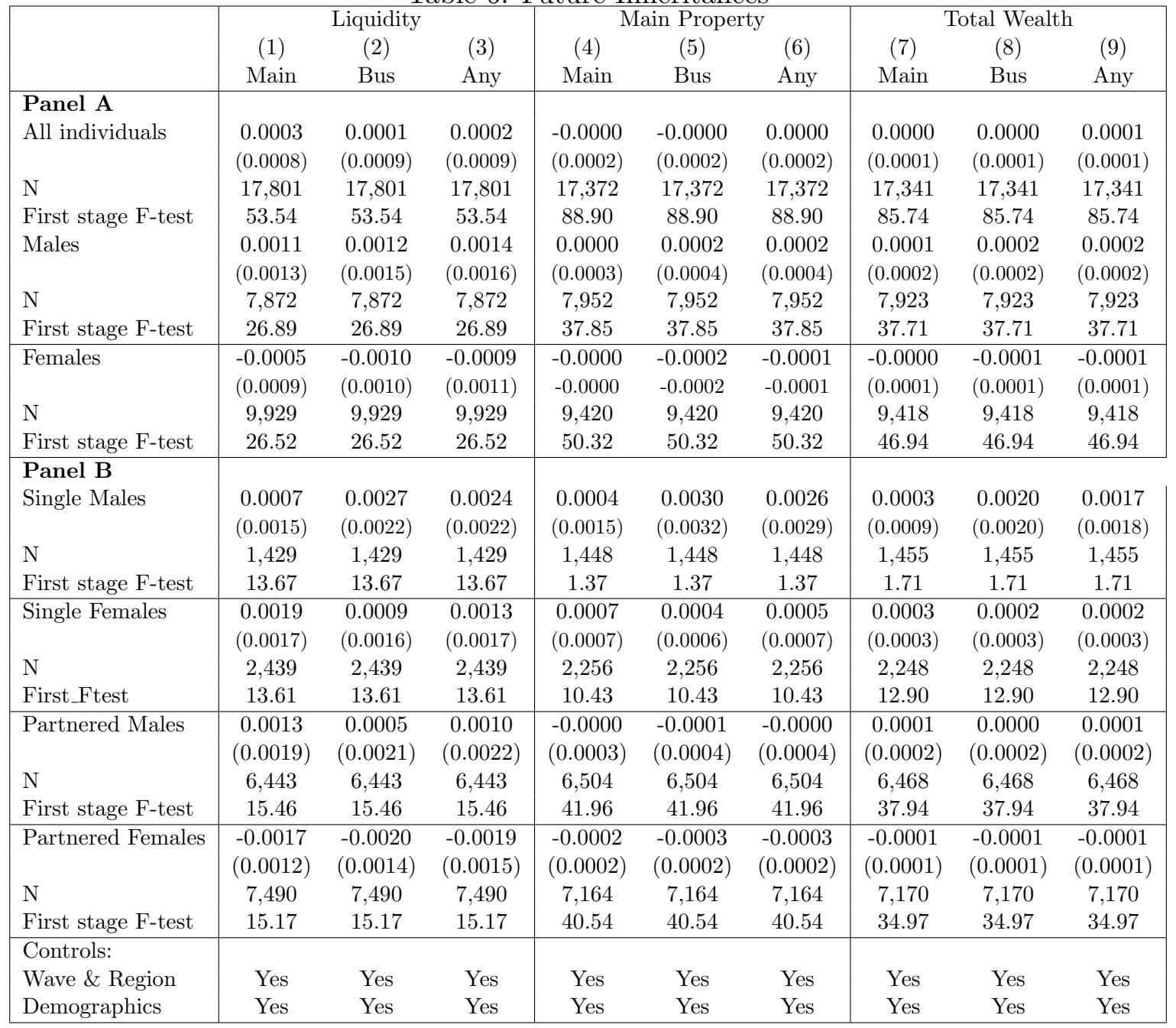

Notes: The table shows IV estimates of self-employment start in the main job, a business start or any entreneurial start within the past two years on wealth measures (in $£ 1,000$ s) instrumented with the log of future inheritances received. Robust standard errors, clustered by individual, are reported in parentheses. ${ }^{*} p<0.05,{ }^{* *} p<0.01,{ }^{* * *} p<0.001$.

To examine the effect of future inheritances on past entrepreneurial entry we exploit the longitudinal aspect of the Wealth and Assets Survey. Specifically for individuals enumerated in more than one wave, we consider whether they are a new enterprise starter in the first wave that they were observed in as a function of any inheritance they received in future waves they were enumerated in. The results are presented in Table 6 . We can see that the first stage is significant in most cases indicating that there is indeed a relationship between current wealth and future 
inheritances. However the relationship is considerably weaker than when past inheritances were considered. Importantly the second stage estimates do not reflect the relationships observed in Table 4 (significant positive effects driven by the response for women, predominantly single females). The estimates are far smaller, we even see a change of sign for females, and they are not significantly different from zero in all cases. We therefore conclude that although we do not rule out a positive correlation between wealth and the probability of inheritance receipt, future inheritances do not exert an important influence on the entry to entrepreneurship.

\section{Discussion}

Our analysis indicates that positive impact of an increase in wealth is driven predominantly by single females. The estimates reveal that a $£ 1,000$ increase in liquidity induced by the receipt of an inheritance in the past 5 years is associated with a $0.12,0.22$ and 0.23 percentage point increase in the respective probabilities of starting self-employment, a business, or one of these enterprises within the past 2 years. That the coefficient on business starts is not different to the composite measure, and almost double in magnitude of the entry to self-employment suggests that reports of self-employment alone, as widely used in previous analyses, may understate entrepreneurship entry effects.

The estimated impact on business starts is non-trivial, constituting an $8.5 \%$ increase in business entry relative to the sample mean. This response is large in comparison to the findings of Holtz-Eakin, Joulfaian, and Rosen (1994) who used matched administrative data on estate tax and personal income tax returns to investigate how the receipt of an inheritance affects the entrepreneur decision, their results suggesting that a $\$ 100,000$ inheritance increases the probability of a transition into self-employment by 3.3 percentage points ( $14 \%$ relative to the sample mean). However it should be noted that their data is restricted to only individuals who receive substantial inheritances, so may not be directly comparable. That the response to an increase in property or total wealth is muted is not surprising as these wealth measures include more illiquid assets which may be limited in their ability to be used as seed capital for starting a business, and underlines that a relaxation of financial constraints (liquidity) has a more salient effect on entrepreneurial start-ups. Nevertheless, we can see that the same result transfers through qualitatively: the relaxing wealth constraints has a significant impact for women only and this result is predominantly driven by single women.

We further support this evidence by examining features of the 4,604 individual businesses that are enumerated in the WAS, displayed in Table 7. Approximately two thirds of the businesses are owned by men, which are on average older than the businesses owned by women. However, there are no significant gender disparities in business size, as measured by the number of employees. Respondents are asked regarding the sources of funding to start the business, in non-mutually exclusive categories. We note that only $3 \%$ of businesses were inherited, indicating that receiving 
an inheritance has a negligible direct effect on owning a business, which implies that our exclusion restriction is valid. $77 \%$ of business ventures used the business owner's own money as start-up funding. This empirical finding is consistent with the viewpoint of Knight (1921) who asserted that it is entrepreneurs rather than investors who mainly bear the risk of new enterprises. Single individuals in particular are marginally more likely to use their own money to start a business, whereas individuals in dual households are proportionately more likely to have obtained a loan. This observation may reflect differences in credit accessibility faced by single individuals. In particular, single women have a lower propensity to have started a business after obtaining a formal loan. This is particularly interesting in light of our results which show that relaxing liquidity constraints for single women has the largest impact on business start-ups. Therefore an important policy implication of our analysis is that providing assistance to this group in particular would increase the proportion transitioning into entrepreneurship.

Table 7: Business Characteristics

\begin{tabular}{|lccc|ccc|ccc|}
\hline & \multicolumn{3}{c}{ All individuals } & \multicolumn{3}{c|}{ Single individuals } & \multicolumn{3}{c|}{ Partnered individuals } \\
& All & Men & Women & All & Men & Women & All & Men & Women \\
\hline Inherited Business & 0.029 & 0.030 & 0.027 & 0.016 & 0.021 & 0.009 & 0.032 & 0.032 & 0.031 \\
& $(0.17)$ & $(0.17)$ & $(0.16)$ & $(0.13)$ & $(0.14)$ & $(0.10)$ & $(0.18)$ & $(0.18)$ & $(0.17)$ \\
Own Money & 0.773 & 0.775 & 0.770 & 0.806 & 0.809 & 0.803 & 0.767 & 0.769 & 0.762 \\
& $(0.42)$ & $(0.42)$ & $(0.42)$ & $(0.40)$ & $(0.39)$ & $(0.40)$ & $(0.42)$ & $(0.42)$ & $(0.43)$ \\
Formal Loan & 0.125 & 0.126 & 0.124 & 0.096 & 0.106 & 0.082 & 0.131 & 0.129 & 0.134 \\
& $(0.33)$ & $(0.33)$ & $(0.33)$ & $(0.29)$ & $(0.31)$ & $(0.27)$ & $(0.34)$ & $(0.34)$ & $(0.34)$ \\
Informal Loan & 0.051 & 0.054 & 0.046 & 0.046 & 0.046 & 0.047 & 0.052 & 0.056 & 0.046 \\
& $(0.22)$ & $(0.23)$ & $(0.21)$ & $(0.21)$ & $(0.21)$ & $(0.21)$ & $(0.22)$ & $(0.23)$ & $(0.21)$ \\
Business Size & 5.129 & 5.439 & 4.544 & 3.275 & 3.308 & 3.230 & 5.500 & 5.803 & 4.884 \\
(Employees) & $(33.34)$ & $(32.64)$ & $(34.64)$ & $(23.64)$ & $(16.88)$ & $(30.49)$ & $(34.95)$ & $(34.61)$ & $(35.64)$ \\
Age of Business & 8.479 & 9.246 & 7.027 & 7.838 & 9.279 & 5.897 & 8.605 & 9.240 & 7.314 \\
& $(8.76)$ & $(9.15)$ & $(7.75)$ & $(9.28)$ & $(10.23)$ & $(7.39)$ & $(8.65)$ & $(8.96)$ & $(7.81)$ \\
\hline $\mathrm{N}$ & 4,604 & 3,020 & 1,584 & 753 & 434 & 319 & 3,851 & 2,586 & 1,265 \\
\hline
\end{tabular}

Notes: The table shows the sample means of characteristics of businesses enumerated in the WAS. Standard deviations are reported in parentheses.

Recent policy initiatives have been implemented by the UK Government to encourage entrepreneurial start-ups. The New Enterprise Allowance, launched in 2011, provides a weekly allowance in the first 6 months for individuals starting self-employment who were previously in receipt of unemployment benefits. Additionally these individuals could apply for a governmentfunded loan to help with start-up costs, and were also offered non-financial support, such as free legal advice and business mentoring. Following early success, the start-up loan programme was extended to all individuals seeking small loans to start an entrepreneurial enterprise ${ }^{6}$. In 2013 a parallel initiative to meet the specific needs of the ex-military personnel and their families, $\mathrm{X}$-Forces, was introduced.

\footnotetext{
${ }^{6}$ Initially the extended programme was targeted to 18-24 year olds only, but this restriction was removed as demand was so high. Eligibility for the weekly allowance continued to be restricted to individuals in receipt of benefits, with the aim that within 6 months self-employment income should be sufficient to replace all benefits.
} 
Take-up statistics of these schemes indicate that $37 \%$ of applications are from women. Although this figure is consistent with the percentage of female-owned businesses, in light of our results a policy designed in particular to meet the needs of liquidity constrained women, similar in scope to the X-Forces programme, would result in a substantial increase to entrepreneurship entry.

\section{Conclusion}

We have examined the impact of wealth constraints on new business formation using a new data source, containing especially rich wealth measures and definitions of entrepreneurship. Consistent with existing findings in the literature, our instrumental variables estimates, using inheritances as an instrument, show that individual wealth has a causal effect on entrepreneurial activity. The new results we offer, comprising our main contribution to the literature, relates to the importance of gender heterogeneity in this relationship.

We have uncovered that single women primarily drive the relationship between wealth and new business formation in the data as a whole. The impact for single women is non-trivial, a $£ 1,000$ increase in liquidity results in an increase in the probability of starting a business of $8.5 \%$ relative to the sample mean.

We further support our evidence by examining features of businesses reported in the Wealth and Assets Survey. In particular, businesses owned by single women are less likely to have been started after obtaining a formal loan. Our results suggest that a public policy programme specifically targeted to meet the needs of liquidity-constrained women could be effective in further accelerating the rate of female entrepreneurship.

\section{References}

Blanchflower, D. G. and A. J. Oswald (1998). What Makes an Entrepreneur? Journal of Labor Economics 16(1), pp. 26-60.

Disney, R. and J. Gathergood (2009). Housing wealth, liquidity constraints and self-employment. Labour Economics 16(1), 79 - 88.

Evans, D. S. and B. Jovanovic (1989). An Estimated Model of Entrepreneurial Choice under Liquidity Constraints. Journal of Political Economy 97(4), pp. 808-827.

Evans, D. S. and L. S. Leighton (1989). Some Empirical Aspects of Entrepreneurship. The American Economic Review 79(3), pp. 519-535.

Fairlie, R. W. and H. A. Krashinsky (2012). Liquidity Contraints, Household Wealth and Entrepreneurship revisited. Review of Income and Wealth 58(2), 279-306. 
Holtz-Eakin, D., D. Joulfaian, and H. S. Rosen (1994). Entrepreneurial Decisions and Liquidity Constraints. The RAND Journal of Economics 25(2), pp. 334-347.

Knight, F. H. (1921). Risk, uncertainty and profit. New York: Hart, Schaffner and Marx.

Office of National Statistics (2014). Self-employed workers in the UK. UK Statistics Authority.

Taylor, M. P. (2001). Self-Employment and Windfall Gains in Britain: Evidence from Panel Data. Economica 68(272), pp. 539-565. 